\title{
Application of algae in biomonitoring and phytoextraction of heavy metals contamination in urban stream water
}

\author{
${ }^{1^{*} \text { K. Sekabira; }}{ }^{2}$ H. Oryem Origa; ${ }^{3}$ T. A. Basamba; ${ }^{2}$ G. Mutumba; ${ }^{2}$ E. Kakudidi \\ ${ }^{1}$ Department of the Environment, School of Engineering and Applied Science, Kampala International University, \\ P. O. Box 20000, Kampala, Uganda \\ ${ }^{2}$ Department of Botany, Faculty of Science, Makerere University, P. O. Box 7062, Kampala, Uganda \\ ${ }^{3}$ Department of Soil Science, Faculty of Agriculture, Makerere University, P. O. Box 7062, Kampala, Uganda \\ Received 28 August 2010; revised 25 October 2010; accepted 15 November 2010; availabe online 1 December 2010
}

\begin{abstract}
Biological technologies for wastewater remediation techniques employed to remove contaminants in urban stream water are increasingly receiving attention worldwide. The purpose of this study was therefore to determine the concentrations of lead, cadmium, copper, zinc, manganese and iron in algal biomass and establish the feasibility of using algae in phytoextraction and bio-monitoring of environmental quality. Analysis of algal biomass samples in the Nakivubo urban stream ecosystem, Kampala, Uganda, showed that there was contamination by lead, cadmium, copper and zinc as indicated by enrichment factor and pollution load index values. It is suspected that industrial and vehicular emissions are the major sources of these pollutants. Calculated bio-concentration factor was $\geq 1000$ but with low concentration thresholds in each element, suggesting that algal biomass was a very good heavy metal accumulator. The bio-concentration values in algal biomass were found to be in the order of copper $>$ zinc $>$ lead $>$ cadmium in the Nakivubo Channelized stream. In conclusion, algae can be a promising aquatic bio-filter plant for phytoextraction and bio-monitoring of polluted urban stream ecosystems and wastewater.
\end{abstract}

Keywords: Bio-filter; Biomass; Green algae; Phytosorption; Wastewater

\section{INTRODUCTION}

Recent developments in environmental research have revealed that many living organisms can accumulate certain toxicants to body concentrations much higher than present in their environments (Nyangababo et al., 2005a; Igwe et al., 2008; Kord et al., 2010). This makes chemical analyses in biota important for use in routine assessment and monitoring procedures (Lam and Gray, 2003; Nwuche and Ugoji, 2008). Body contaminant concentrations can further be used in assessing and monitoring the uptake of contaminants by living organisms and the increase in concentrations of pollutants from the environment to the organisms (bioaccumulation/bio-concentration). Green algae have been recognised as one of the most important primary producers in some aquatic ecosystems that have a role to play in the regulation of dissolved oxygen in water through the phenomenon

*Corresponding Author Email: ssekaba@gmail.com Tel.: +256772 855348 of photosynthesis. The adsorption, phytosorption and affinity of algae for heavy metal cations in wastewater treatment because of its high negatively charged surface (cell wall components) have been acknowledged for a long time. This property gives algae an added advantage as heavy metal accumulator in view of phytoextraction of such elements in urban stream ecosystems (Chmielewska and Medved, 2001; Kar et al., 2008 ). Algae have been qualified as a precise biomonitoring tool for determining and quantifying of heavy metals in aquatic ecosystems (Levkov and Krstic, 2002; Shah et al., 2009).

Biological water remediation techniques are preferred to chemical and physical treatment technologies because of their effectiveness, low cost and reduced impact on ecosystem (Thangavel and Subbhuraam, 2004). Recently, interests have focused on the study of aquatic plants in remediation and biomonitoring of heavy metal contaminants in aquatic 
ecosystems (Girgin et al., 2010; Nouri et al., 2009).. In view of this, the environment is able to absorb pollutants and clean up itself through natural biological processes as bioremediation (Wuana et al., 2010). The uses of submerged aquatic plants in water quality assessment have been recognized and are reported to bio-concentrate and scavenge heavy metals in wastewater (Scott, 1992; Goyal et al., 2008). Plants have the ability to bioconcentrate metals at levels 100 -fold greater than those typically measured in non-accumulator plants and can be categorised as $\mathrm{Cd}>100 \mathrm{mg} / \mathrm{kg}, \mathrm{Pb}$ and $\mathrm{Cu}>1000 \mathrm{mg} / \mathrm{kg}$ and $\mathrm{Zn}$ and $\mathrm{Mn}>10000 \mathrm{mg} / \mathrm{kg}$ (Baker and Brooks, 1989). The extreme level of metal tolerance in vascular plants is called hyper-accumulation (Baker and Brooks, 1989). BCF values $\geq 1000$ (Zayed et al., 1998) can be used together with the concentration thresholds in each element as mentioned by Baker and Brooks (1989) to characterise a plant as a good accumulator (hyperaccumulator). Bioconcentration Factor (BCF) is regarded as a better indicator to classify a particular plant as a hyperaccumulator because BCF takes into account the trace element concentrations in the solution (Zayed et al., 1998). BCF standard is applied as a threshold, above which a substance is considered bio-accumulative and therefore able to cause long term environmental impact. The objectives of this study were: 1) to determine the concentrations of $\mathrm{Pb}, \mathrm{Cd}, \mathrm{Cu}, \mathrm{Zn}, \mathrm{Mn}$ and $\mathrm{Fe}$ in algal biomass in urban stream water .2) to assess the feasibility of using algae in bio-monitoring of environmental quality. 3) establish the possibility of using algae for phytoextraction in urban stream water and wastewater. This study was conducted between August, 2008 and November 2009, along the Nakivubo Channelized stream of Kampala in Uganda.

\section{MATERIALSANDMETHODS}

Study area and sites

The sampling area [0 $0^{0} 15^{\prime} \mathrm{N}$ and $32^{\circ} 30^{\prime} \mathrm{E}$ ] is shown in Fig. 1. Algal materials were sampled from different localities along the Nakivubo Channelized stream (Table 1). The stream drains through Kampala city center, the most industrialised areas and Nakivubo wetland before discharging into Lake Victoria. The channel is the major recipient of runoff, organic and inorganic industrial and domestic waste effluents. Nakivubo Channel was constructed basically to carry storm water from Kampala city into Lake Victoria to minimise flooding and ponding effects.

\section{Sampling and laboratory analytical procedures}

Algal samples were collected for over one year along the Nakivubo drainage system (Table 1) as described by Chmieleseská and Medved' (2001). Samples were oven dried at $105^{\circ} \mathrm{C}$ for $2 \mathrm{~h}$ and homogenized into a finegrained

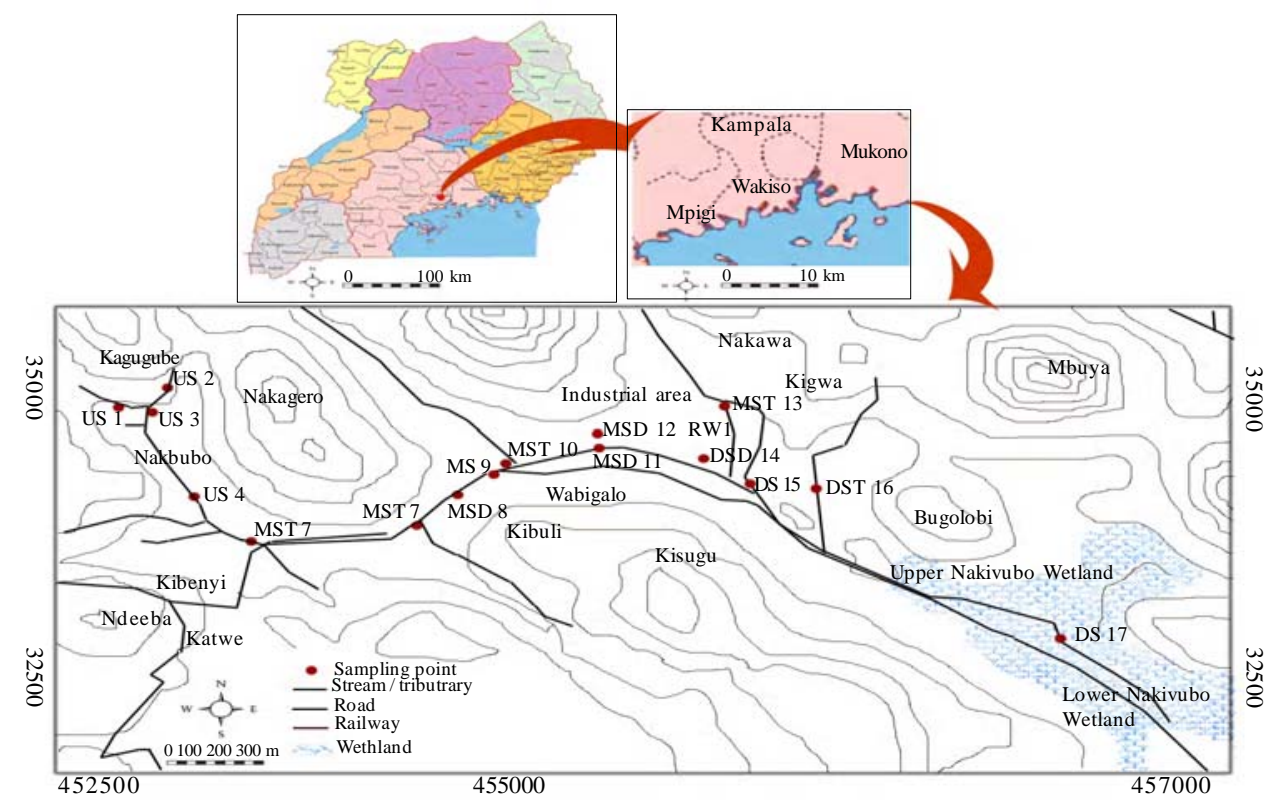

Fig. 1: Map of Uganda showing the locations of the sampling sites along the Nakivubo Channelized stream in Kampala 
Int. J. Environ. Sci. Tech., 8 (1), 115-128, Winter 2011

Table 1: Location and description of activities and establishments

\begin{tabular}{|c|c|c|c|c|}
\hline \multirow{2}{*}{$\begin{array}{l}\text { Site* } \\
\text { Upstream }\end{array}$} & \multirow[t]{2}{*}{ Code } & \multicolumn{2}{|c|}{ GPS Readings } & \multirow[t]{2}{*}{ Activity/Establishment } \\
\hline & & Lat. & Long. & \\
\hline Bativa Hotel Bridge & US02 & 0.324 & 32.5726 & $\begin{array}{l}\text { Car washing bay, gas/fuel station, slum residential and commercial } \\
\text { and seepage }\end{array}$ \\
\hline Nakivubo Stadium Bridge & US04 & 0.3169 & 32.5723 & $\begin{array}{l}\text { Recreational, commercial, market, vehicle traffic, bus park, gas/petro } \\
\text { station and seepage }\end{array}$ \\
\hline \multicolumn{5}{|l|}{ Tributaries } \\
\hline Kayunga Stream & MT07 & 0.3081 & 32.5782 & $\begin{array}{l}\text { Solid waste dump sites, horticulture, recreational, slum and } \\
\text { residential, vehicle traffic, gas/petro station }\end{array}$ \\
\hline Kitante Stream & MT10 & 0.3099 & 32.5891 & $\begin{array}{l}\text { Horticulture, recreational, residential and commercial, vehicle traffic, } \\
\text { gas/petro station }\end{array}$ \\
\hline Lugogo Stream & MT13 & 0.3191 & 32.6011 & $\begin{array}{l}\text { Vehicle traffic, Commercial, residential and industrial, Electric power } \\
\text { station, horticulture, carpentry works, pole treatment and seepage }\end{array}$ \\
\hline Kibira Road Stream & DT16 & 0.3142 & 32.611 & Battery, plastic and paper factory, industries, and gas/petro station \\
\hline
\end{tabular}

size. Decomposition of samples was performed using 20.0 $\mathrm{mL}$ fuming $\mathrm{HNO}_{3}$ in open beaker digestion, left over night using a thermalmetrically controlled hot plate. Then 5.0 $\mathrm{mL}$ of hydrogen peroxide was added to complete the digestion and heated again to dryness. The beaker walls were washed with $2.5 \mathrm{~mL}$ of deionised water and heated to boiling point. The digest liquor was transferred into $25.0 \mathrm{~mL}$ flask and filled with deionised water to the mark. Sampling and chemical analysis of water and sediment samples were carried out as described by Sekabira et al, (2010 a, b). Heavy metals were analysed using PerkinElmer model 2380 Flame atomic absorption spectrophotometry. Accuracy of the analytical method was evaluated by comparing the expected metal concentrations in certified reference materials with the measured values. Simultaneous performance of analytical blanks, periodic aspiration of the standard, certified reference (JG-3) and calculation of the average recoveries of heavy metals show that the accuracy of the method was within acceptable limits (Table 2).

\section{Heavy Metal Assessment}

Bio-concentration Factor (BCF) or coefficients: Bioconcentration Factor can be employed to qualify the toxic element accumulation efficiency in plants by comparing the concentrations in the biota (algal biomass) and an external medium (e.g. water).

$\mathrm{BCF}=\mathrm{C}_{\mathrm{b}} / \mathrm{C}_{\mathrm{w}}$
Where, $\mathrm{C}_{\mathrm{b}}$ and $\mathrm{C}_{\mathrm{w}}$ are heavy metal concentrations in the biota $(\mathrm{mg} / \mathrm{kg})$ and in water $(\mu \mathrm{g} / \mathrm{L})$, respectively. BCF was categorised as: $<1$ excluder, metal accumulator $>1$ and $\geq 1000$ a good metal accumulator (Zayed et al., 1998).

Analysis of variance (ANOVA): ANOVA was employed to determine whether groups of variables have the same means on data that are continuous or normally distributed and with homogeneous variance. Additionally, it was employed to assess the relationship between heavy metal concentrations and their elemental interaction at each site.

Correlation analysis: Pearson's correlation analysis was adopted to analyse and establish inter-metal relationship and physico-chemical characteristics of the stream water.

\section{RESULTS AND DISCUSSION}

Heavy metal concentrations in water, algal biomass and sediments

Mean physico-chemical characteristics are indicated in Table 3. Water pH ranged between 6.12 and 9.36 and was within the maximum permissible limit of discharge for wastewater except along Kibira Road and Kitante tributaries. Total dissolved solids ranged between 102.0 and $478.0 \mathrm{mg} / \mathrm{L}$, Total Suspended Solids 3.0 and $733.0 \mathrm{mg} /$ L, EC 5.3 and $961.0 \mu \mathrm{s} / \mathrm{cm}$ and BOD 5.6 and $952.0 \mathrm{mg} / \mathrm{L}$. Nakivubo Stadium Bridge along Nakivubo Channelized stream showed very high BOD and TSS in the upstream

Table 2: Quality control (mean $\pm \mathrm{SD})(\mathrm{mg} / \mathrm{kg}$ trace and $\%$ for elements)

\begin{tabular}{|c|c|c|c|c|c|c|}
\hline Heavy metals & $\mathrm{Pb}$ & $\mathrm{Cd}$ & $\mathrm{Cu}$ & $\mathrm{Zn}$ & Mn (\%) & $\mathrm{Fe}(\%)$ \\
\hline Reference material & 11.7 & 0.054 & 6.81 & 46.5 & 0.055 & 2.58 \\
\hline Percentage Recovery & 85.5 & 92.6 & 99.1 & 103.8 & 87.3 & 91.1 \\
\hline
\end{tabular}


section suggesting high decomposition of organic matter and anoxic conditions.

Table 5 shows metal concentrations $(\mu \mathrm{g} / \mathrm{L})$ in water samples that were collected from Nakivubo stream, its tributaries and Watindo stream. The total mean heavy metal concentrations in the Nakivubo Channelized stream water were in the sequence of Fe $(700 \mu \mathrm{g} / \mathrm{L})>\mathrm{Mn}(610$ $\mu \mathrm{g} / \mathrm{L})>\mathrm{Zn}(36 \mu \mathrm{g} / \mathrm{L})>\mathrm{Pb}(29 \mu \mathrm{g} / \mathrm{L})>\mathrm{Cu}(10 \mu \mathrm{g} / \mathrm{L})>\mathrm{Cd}(4$ $\mu \mathrm{g} / \mathrm{L})$. The mean trace heavy metal concentrations in the water samples from tributaries were Fe $(1.125 \mu \mathrm{g} / \mathrm{L})>\mathrm{Mn}$ $(755 \mu \mathrm{g} / \mathrm{L})>\mathrm{Pb}(77 \mu \mathrm{g} / \mathrm{L})>\mathrm{Zn}(67 \mu \mathrm{g} / \mathrm{L})>\mathrm{Cu}(12 \mu \mathrm{g} / \mathrm{L})>$ $\mathrm{Cd}(6 \mu \mathrm{g} / \mathrm{L})$. The mean concentrations of heavy metals in Watindo stream which is considered to be unpolluted were in the sequence of Fe $(4450 \mu \mathrm{g} / \mathrm{L})>\mathrm{Mn}(160 \mu \mathrm{g} / \mathrm{L})$ $>\mathrm{Pb}(63 \mu \mathrm{g} / \mathrm{L})>\mathrm{Zn}(23 \mu \mathrm{g} / \mathrm{L})>\mathrm{Cu}(8 \mu \mathrm{g} / \mathrm{L})>\mathrm{Cd}(3 \mu \mathrm{g} / \mathrm{L}$ 1). The mean heavy metal levels in tributaries and Watindo stream showed a similar sequence. Results show that elemental concentrations in water are comparable with that reported by Muwanga and Barifaijo (2006) but lower than those reported by Nabulo et al. (2008) in industrial effluents released into the Nakivubo Channelized stream and its tributaries. However, the concentrations of $\mathrm{Pb}$, $\mathrm{Cd}, \mathrm{Cu}, \mathrm{Zn}$ and $\mathrm{Mn}$ in sediments are higher than those reported earlier by Muwanga and Barifaijo (2006). The mean heavy metal concentrations in the algal biomass (Table 5) in the Nakivubo stream followed the trend Fe $(65290.45 \mathrm{mg} / \mathrm{kg})>\mathrm{Mn}(979.275 \mathrm{mg} / \mathrm{kg})>\mathrm{Zn}(349.08 \mathrm{mg} /$ $\mathrm{kg})>\mathrm{Pb}(108.51 \mathrm{mg} / \mathrm{kg})>\mathrm{Cu}(97.94 \mathrm{mg} / \mathrm{kg})>\mathrm{Cd}(1.425$ $\mathrm{mg} / \mathrm{kg}$ ) Table 3. In Nakivubo tributaries, heavy metals were observed in the sequence Fe $(41885.430 \mathrm{mg} / \mathrm{kg})>$ $\mathrm{Mn}(834.253 \mathrm{mg} / \mathrm{kg})>\mathrm{Zn}(462.528 \mathrm{mg} / \mathrm{kg})>\mathrm{Pb}(166.12$ $\mathrm{mg} / \mathrm{kg})>\mathrm{Cu}(50.228 \mathrm{mg} / \mathrm{kg})>\mathrm{Cd}$ (3.008 mg/kg). Watindo stream elemental concentrations followed the sequence $\mathrm{Fe}(47899.010 \mathrm{mg} / \mathrm{kg})>\mathrm{Mn}(1026.890 \mathrm{mg} / \mathrm{kg})>\mathrm{Zn}(119.535$ $\mathrm{mg} / \mathrm{kg})>\mathrm{Pb}(45.875 \mathrm{mg} / \mathrm{kg})>\mathrm{Cu}(24.575 \mathrm{mg} / \mathrm{kg})>\mathrm{Cd}$
( $2.085 \mathrm{mg} / \mathrm{kg}$ ). Heavymetal concentrations in algal biomass followed a similar sequence in Nakivubo tributaries and Watindo stream as well as Nakivubo stream water. Generally, metal ions with greater electronegativity and smaller ionic radii are preferentially sorbed by algal biomass. The concentrations of heavy metals in algal biomass were higher than those in the water and sediments in the Nakivubo Channelized stream sediments and water in the order of Algal biomass > sediments > stream water. This observation differs from the findings made by Levkov and Krstic (2002), since heavy metal concentrations were high in the sediments (sediments > algal biomass > river water) for most of the elements. Lead concentration was exceptionally high in sediments at site DT16 in this study (Muwanga and Barifaijo, 2006).

Table 5 showed high mean heavy metal concentration in algal biomass at site DT16 for Pb, Cd, Zn, and Mn. These high heavy metal concentrations in algae are attributed to Uganda Batteries factory, Plastic manufacture by Uganda House of plastics and a petrol station ( $\mathrm{Pb}$ and $\mathrm{Cd}$ ) and manufacture of galvanised iron sheets by Uganda Baati (Zn). The phenomenon show low heavy metal levels in water with algal biomass (Levkov and Krstic, 2002). The study shows that the value of algal bio-concentration factor at most of the sites including US02, US04, MT07, DT16 and CT03 were greater than 1000. The results of heavy metal bio-concentration in algal biomass qualify it as a good heavy metal accumulator (Conti and Cecchetti, 2003). The high rates of bio-concentration in algae may be attributed to its cell wall components. However, these algal samples showed total concentration in dry biomass $<100 \mathrm{mg} / \mathrm{kg} \mathrm{Cd},<1000 \mathrm{mg} / \mathrm{kg} \mathrm{Cu} \mathrm{Pb}$ and < $10000 \mathrm{mg} / \mathrm{kg}$ $\mathrm{Zn}$ and $\mathrm{Mn}$ (Table 5) and thus algae could not be classified as a hyper-accumulator (Baker and Brooks, 1989). The trend of heavy metal concentrations in the algal biomass

Table 3: Mean physico-chemical characteristics of stream water samples from Nakivubo Channelized stream, tributaries and Watindo stream $(\mathrm{n}=16)$

\begin{tabular}{|c|c|c|c|c|c|c|c|c|c|c|c|c|c|c|c|}
\hline \multirow[b]{2}{*}{ Site* } & \multicolumn{3}{|c|}{ pHw } & \multicolumn{3}{|c|}{ TDS (mg/L) } & \multicolumn{3}{|c|}{ TSS (mg/L) } & \multicolumn{3}{|c|}{$\mathrm{EC}(\mu \mathrm{s} / \mathrm{cm})$} & \multicolumn{3}{|c|}{$\mathrm{BOD}(\mathrm{mg} / \mathrm{L})$} \\
\hline & Mean & Min. & Max. & Mean & Min & Max. & Mean & Min & Max. & Mean & Min. & Max. & Mean & Min & Max. \\
\hline US2 & 7.07 & 6.55 & 7.97 & 178.81 & 145 & 255 & 118.31 & 5 & 733 & 356.75 & 299 & 502 & 36.08 & 5.6 & 188.6 \\
\hline US4 & 7.18 & 6.3 & 7.89 & 251 & 114 & 298 & 195.13 & 48 & 357 & 471.52 & 5.3 & 618 & 166.97 & 58.52 & 952 \\
\hline MT7 & 7.33 & 6.91 & 7.86 & 305.5 & 236 & 361 & 69.19 & 9 & 367 & 612.63 & 479 & 722 & 49.09 & 6.24 & 200 \\
\hline MT10 & 7.09 & 6.59 & 9.35 & 129.69 & 102 & 166 & 24.19 & 6 & 49 & 260.63 & 208 & 335 & 30.31 & 5.18 & 156.2 \\
\hline MT13 & 7.15 & 6.35 & 7.62 & 199.81 & 163 & 478 & 24.13 & 3 & 128 & 405.38 & 328 & 961 & 46.66 & 5.6 & 224 \\
\hline DT16 & 6.86 & 6.12 & 9.36 & 263.56 & 156 & 405 & 115.31 & 18 & 289 & 526.06 & 319 & 807 & 155.87 & 12.46 & 672 \\
\hline CT2 & 7 & 6.55 & 7.72 & 51.83 & 40 & 60.8 & 97.97 & 12 & 877.5 & 103.11 & 80.1 & 122.2 & 16.69 & 2.24 & 38.08 \\
\hline CT3 & 6.88 & 6.51 & 7.51 & 53.19 & 12.8 & 69.6 & 105.87 & 12 & 370 & 106.23 & 25.7 & 140.2 & 31.97 & 5.6 & 197.1 \\
\hline *NEMA & & $6-8$. & & & 1200 & & & 100 & & & & & 50 & & \\
\hline
\end{tabular}

* NEMA (2006/2007) maximum permissible limits of discharge of wastewater into aquatic habitats; pH-w water pH.

For description of *sites refer to Table 1 
correspond to the heavy metal content in water, sediments and BCF at each sampled site.

Heavy metal concentrations in the Nakivubo stream sediments (Table 5) followed the trend Fe (49974.670 mg/ $\mathrm{kg})>\mathrm{Mn}(474.030 \mathrm{mg} / \mathrm{kg})>\mathrm{Zn}(370.370 \mathrm{mg} / \mathrm{kg})>\mathrm{Pb}$ $(159.820 \mathrm{mg} / \mathrm{kg})>\mathrm{Cu}(53.060 \mathrm{mg} / \mathrm{kg})>\mathrm{Cd}(1.670 \mathrm{mg} / \mathrm{kg})$. The mean heavy metal concentrations in the tributary sediments followed the order Fe $(47369.330 \mathrm{mg} / \mathrm{kg})>\mathrm{Mn}$ $(563.080 \mathrm{mg} / \mathrm{kg})>\mathrm{Zn}(251.450 \mathrm{mg} / \mathrm{kg})>\mathrm{Pb}(150.660 \mathrm{mg} /$ $\mathrm{kg})>\mathrm{Cu}(34.450 \mathrm{mg} / \mathrm{kg})>\mathrm{Cd}(1.010 \mathrm{mg} / \mathrm{kg})$. Watindo stream sediments heavy metal concentrations followed the order Fe $(65874.670 \mathrm{mg} / \mathrm{kg})>\mathrm{Mn}(109-.530 \mathrm{mg} / \mathrm{kg})>$ $\mathrm{Zn}(55.330 \mathrm{mg} / \mathrm{kg})>\mathrm{Pb}(37.220 \mathrm{mg} / \mathrm{kg})>\mathrm{Cu}(13.970 \mathrm{mg} /$ $\mathrm{kg})>\mathrm{Cd}(0.970 \mathrm{mg} / \mathrm{kg})$. Generally, heavy metals in the Nakivubo stream, its tributaries and Watindo stream sediments follow a similar elemental concentration trend. Sediments accumulated more heavy metals than the water in this study as revealed by Eja et al. (2003), suggesting high deposition of heavy metals into stream sediments. High heavy metal concentrations in sediments are attributed to vehicular and industrial emissions and residential establishments along the Nakivubo channel and support the findings of Nyangababo et al, (2005a) and Muwanga and Barifaijo (2006). Analysis of variance (ANOVA) was employed to determine whether heavy metal variables have the same mean on data that are normally distributed (Table 4). ANOVAresults were based on BCF of heavy metals in algal biomass. Sites showed no significant effect on variations between means of heavy metal bioaccumulation factor ( $p>0.05$ ) (Table 4). This suggests that green algae follow a similar pattern of heavy metal sequestration since they are not differentiated into plant parts and heavy metals are mobile in solution form.

The mean BCF in all of the sites and elements in algal biomass were several orders higher (BCF > 1) (Table 6). The mean BAF values in algal biomass of the Nakivubo Channelized stream follow the trend $\mathrm{Fe}(93658.66)>\mathrm{Cu}$ (10831.39) > Zn (9081.62) > Pb(6868.95) > Mn (1649.04) >
Cd (383.23). The mean BAF values in tributaries can therefore be ranked in order of decreasing magnitude as $\mathrm{Fe}(63768.66)>\mathrm{Zn}(6822.24)>\mathrm{Cu}(4876.68)>\mathrm{Mn}(2212.23)$ $>\mathrm{Pb}(1830.13)>\mathrm{Cd}$ (567.77). Also Watindo stream algal biomass BCF values were ranked as Fe (10620.75) $>$ Mn (6426.08) $>\mathrm{Zn}(5273.72)>\mathrm{Cu}(3122.41)>\mathrm{Cd}(852.00)>\mathrm{Pb}$ (814.70). BCF values ranged from 30.84 to 482.01 for $\mathrm{Pb}$, 1.08 to 4.53 for $\mathrm{Cd}, 15.29$ to 126.69 for $\mathrm{Cu}, 105.7$ to 1138.35 for Zn, 714.07 to 1072.25 for $\mathrm{Mn}$ and 27364.27 to 83075.05 for Fe. The sampled algae showed that BCF ranged between 411.20 and 12669.00 for $\mathrm{Pb}, 252.0$ and 1392 for $\mathrm{Cd}, 1816.57$ and 15836.25 for $\mathrm{Cu}, 4450.53$ and 11422.17 for Zn, 436.15 and 6169.64 for Mn and 14865.31 and 95011 for Fe.

Cluster Analysis (CA) and Factor Analysis (FA): Cluster analysis was performed on the data using average linkage and correlation coefficient distance. Results of cluster analysis are shown in Fig. 2. Two groups of elemental associations with eigenvalues $>1$ were extracted in the analyses. Heavy metal elements were fused into groups or clusters because of their relative elemental concentration in algal biomass at each site and their similarity coefficients. Group I contains $\mathrm{Pb}, \mathrm{Cu}, \mathrm{Cd}$ and $\mathrm{Zn}$ as well as sediment $\mathrm{pH}$. Group II contains $\mathrm{Mn}$ and Fe (Fig. 3).

Biplot of sites and elemental concentrations (Fig. 2) suggest that inflows from Kibira Road and Lugogo are sources of $\mathrm{Pb}$, Kitante streams are sources of $\mathrm{Pb}, \mathrm{Cu}$ and Zn, whereas inflows from Kayunga stream are loaded with $\mathrm{Fe}, \mathrm{Mn}$ and Cd. Bativa Hotel Bridge in flows are sources of $\mathrm{Cd}, \mathrm{Cu}$ and $\mathrm{Zn}$ to Nakivubo Channelized stream. The first two factors account for $79.9 \%$ of the total variance in the data set. The rotated factor matrix is explained by the two factors with high communalities of elements except Cd. The first factor accounts for $53.0 \%$ of the total variance and contains $\mathrm{Mn}$ and $\mathrm{Fe}$ with high variable loadings on this factor and corresponds to group II of the cluster analysis. This association may be due to their common occurrence in the basic rock attributed to

Table 4: One-way ANOVA results for sites and heavy metal concentration variables (Dependant variables were log-normal transformed)

\begin{tabular}{|c|c|c|c|c|c|c|}
\hline Source of variation & Dependent variables & SS & $\mathrm{DF}$ & MS & $\mathrm{F}$ & $\mathrm{p}$ \\
\hline \multirow[t]{6}{*}{ Sites } & $\mathrm{Pb}$ & 0.530 & 2 & 0.265 & 1.128 & 0.394 \\
\hline & $\mathrm{Cd}$ & 0.063 & 2 & 0.031 & 0.349 & 0.721 \\
\hline & $\mathrm{Cu}$ & 0.259 & 2 & 0.129 & 2.116 & 0.216 \\
\hline & $\mathrm{Zn}$ & 0.051 & 2 & 0.026 & 1.568 & 0.296 \\
\hline & Mn & 0.539 & 2 & 0.269 & 2.339 & 0.192 \\
\hline & $\mathrm{Fe}$ & 1.029 & 2 & 0.515 & 4.584 & 0.074 \\
\hline
\end{tabular}

DF-degree of freedom; F-factor mean square SS- Sum of Squares; MS- Mean Square; P = 0.05 


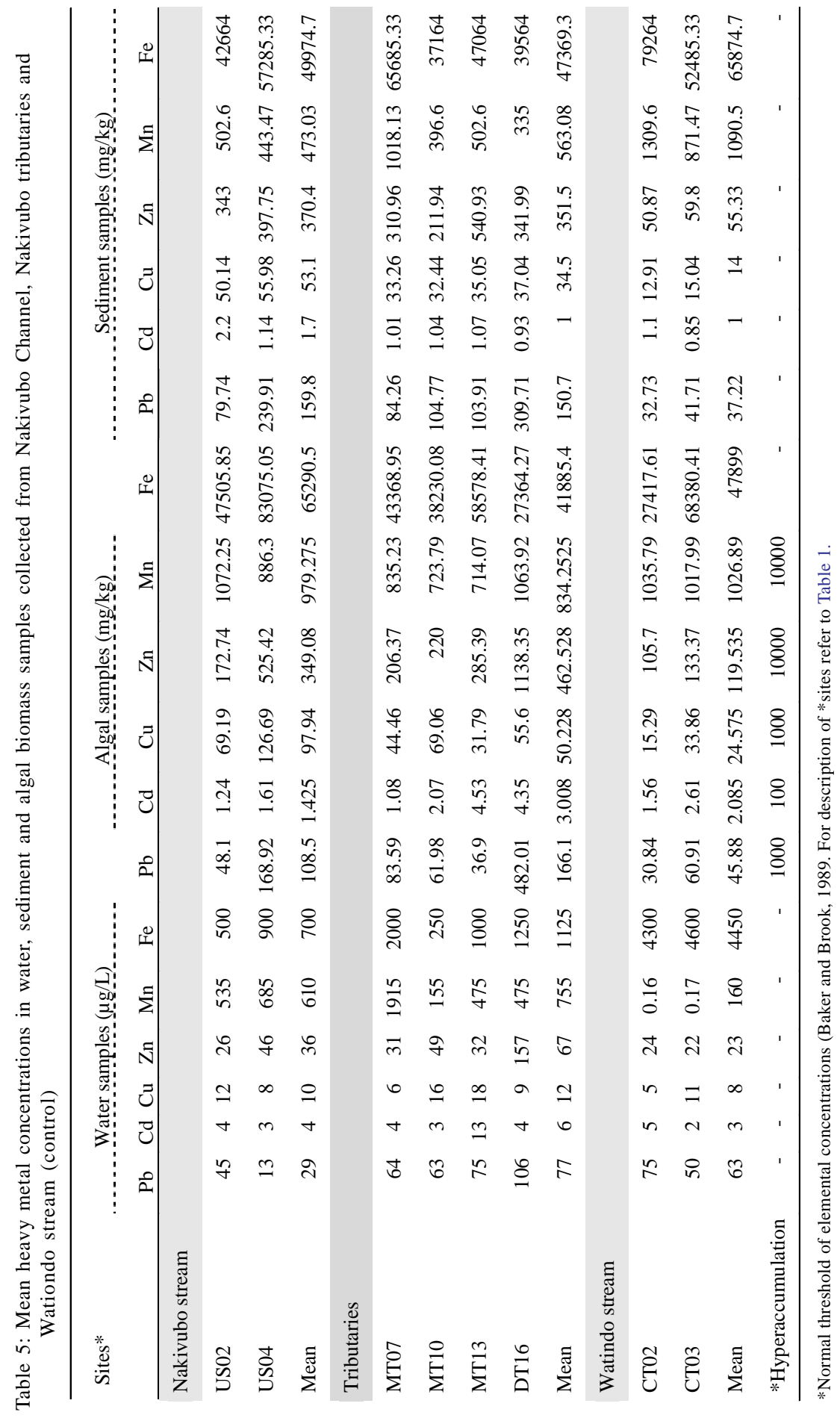


terriginous influence. The second factor accounts for 26.9 $\%$ of the variance and contains $\mathrm{Pb}, \mathrm{Cd}, \mathrm{Cu}$ and $\mathrm{Zn}$ as well as water $\mathrm{pH}$ with high variable loadings and corresponds to group I of cluster analysis. This may suggest the influence of vehicular and industrial emissions and water $\mathrm{pH}$ as the controlling factor, whereas the association of $\mathrm{Cd}$ and $\mathrm{Zn}$ may be due to their geochemistry.

Tables 8 (a) to 10 represent correlation coefficients for the data obtained for Nakivubo Channelized stream (US02 and US04), its tributaries namely Kayunga stream (MT07), Kitante stream (MT10), Lugogo stream (MT13) and Kibira Road stream (DT16), respectively, for possible paired elements. Table 8 (a) shows that elemental pairs Cd-s/ Cu-a, Cu-s/Cu-a, Mn-s/Mn-a, Fe-s/Fe-a, Cu-w/Mn-a, Mnw/Fe-a, Fe-w/Fe-a, Mn-w/Pb-s, Fe-w/Pb-s, Cu-s/Cd-s, Zns/Cu-s, Fe-s/Mn-s, Cu-w/Mn-s, Fe-w/Mn-w, Zn-w/pHand $\mathrm{Zn}-\mathrm{w} / \mathrm{BOD}$ are positively correlated with the same elements and each other. The rest of the elemental pairs were not significantly correlated with each other. In Table 8 (b), elemental pairs Pb-s/Pb-a, Zn-a/Cu-a, Mn-a/Zn-a, $\mathrm{Fe}-\mathrm{a} / \mathrm{Cu}-\mathrm{a}, \mathrm{Fe}-\mathrm{a} / \mathrm{Zn}-\mathrm{a}, \mathrm{Fe}-\mathrm{a} / \mathrm{Mn}-\mathrm{a}, \mathrm{Fe}-\mathrm{s} / \mathrm{Zn}-\mathrm{a}, \mathrm{Mn}-\mathrm{s} / \mathrm{Mn}-$ a, Fe-s/Mn-a, Fe-s/Fe-a, Zn-s/Pb-s, Fe-s/Pb-s, Pb-w/Cds, Pb-w/Cu-s, Mn-s/Zn-s, Fe-s/Zn-s, Fe-s/Mn-s Mn-w/ Zn-a, Mn-w/Mn-a, Fe-w/Cu-a, Fe-w/Zna, Fe-w/Mn-a, Few, Fe-a, Fe-a/BOD, Zn-s/BOD and Fe-w/Mn-w are positively correlated with the same elements and each other except $\mathrm{Cu}-\mathrm{a} / \mathrm{Cd}$-a which was negatively correlated. The rest of the elemental pairs were not significantly correlated. Table 9 (a) shows that elemental pairs Cd-a/ Pb-a, Cu-a/Cd-a, Zn-a/Cd-a, Pb-w/Pb-a, Mn-a/Zn-a, Fe-a/ Zn-a, Fe-a/Mn-a, Cu-w/Cd-a, Cu-w/Zn-a, Cu-w/Fe-a, Mns/Cd-a, Fe-s/Cd-a, Mn-s/Zna, Fe-s/Zm-a, Pb-s/Cd-w, Cus/Cd-w, Zn-s/Cd-w, Mn-s/Pb-w, Fe-s/Pb-w, Mn-s/Cu-w, $\mathrm{Fe}-\mathrm{s} / \mathrm{Cu}-\mathrm{w}, \mathrm{Fe}-\mathrm{w} / \mathrm{Mn}-\mathrm{w}, \mathrm{Cd}-\mathrm{s} / \mathrm{Pb}-\mathrm{s}, \mathrm{Cu}-\mathrm{s} / \mathrm{Pb}-\mathrm{s}, \mathrm{Cu}-\mathrm{s} / \mathrm{Cd}-$ s, Fe-s/Mn-s, Zn-a/pH-w, Mn-a/pH-w, Fe-a/pH-w, Mn-a/ $\mathrm{EC}$ and $\mathrm{Fe}-\mathrm{a} / \mathrm{pH}$ are positively correlated with the same elements and each other, except $\mathrm{Cu}-\mathrm{a} / \mathrm{EC}, \mathrm{Zn}-\mathrm{a} / \mathrm{DO}, \mathrm{Mn}-$ a/DO, Fe-a/DO, Mn-w/EC and Fe-w/EC which were negatively correlated. The rest of the elemental pairs were not significantly correlated. Elemental pairs in Table 9 (b) shows that Pb-s/Cd-a, Fe-a/Zn-a, Zn-s/Zna, Mn-s/Zn-a, Fe-s/Zn-a, Zn-s/Mn-a, Mn-s/Fe-a, Fe-s/Fe-a, Cd-w/Mna, Zn-w/Fe-a, Mn-s/Zn-s, Fe-s/Zn-s, Cd-w/Mn-a, Cd-w/ Zn-s, Fe-s/Mn-s and Mn-w/Cd-w and Fe-w/Cd-w, as well as $\mathrm{Mn}-\mathrm{a} / \mathrm{pH}, \mathrm{Zn}-\mathrm{s} / \mathrm{pH}, \mathrm{Cd}-\mathrm{a} / \mathrm{BOD}$ and $\mathrm{Pb}-\mathrm{s} / \mathrm{BOD}$ are positively correlated with each other except Fe-w/Zn-w and $\mathrm{Mn}-\mathrm{a} / \mathrm{DO}$ which are negatively correlated. The rest of the pairs were not significantly correlated. Table 9 (c) shows that Cu-a/Cd-a, Zn-a/Cd-a, Zn-a/Cu-a, Mn-a/Cda, Mn-a/Zn-a, Fe-a/Zn-a, Fe-a/Mn-a, Fe-a/Mb-a, Zn-w/ Mn-a, Fe-s/Fe-a, Zn-w/Fe-a, Cu-w/Pb-s, Fe-s/Zn-s, Znw/Zn-s, /Mn-w/Zn-s, Fe-w/Zn-s, Fe-s/Mn-s, Zn-w/Mns, Zn-w/Fe-s, Mn-w/Fe-s, Fe-w/Fe-s, Cd-w/Pb-w, Fe-w/ Zn-w, Mn-w/Zn-w, Fe-w/Zn-w, Fe-w/Zn-w and, Pb-s/EC, Zn-w/EC, Cu-w/DO, Cu-s/DO, as well as Mn-w/Ec were positively correlated with each other, except Zn-s/EC, Fea/Temp, $\mathrm{Pb}-\mathrm{s} / \mathrm{pH}$ and $\mathrm{Zn}-\mathrm{w} / \mathrm{Temp}$ which were negatively correlated. The rest of the pairs were not significantly correlated. Table 9 (d) shows that Mn-a/Zn-a, Fe-a/Zn-a, Fe-a/Mn-a, Zn-s/Cu-a, Mn-s/Cd-a, Pb-w/Pb-a, Mn-w/Zna, Mn-w/Mn-a, Mn-w/Fe-a, Fe-w/Zn-a, Fe-w/Mn-a, Few/Fe-a, Cu-w/Fe-s, Zn-w/Fe-s, Zn-w/Cu-w, Fe-w/Mn-w and $\mathrm{Pb}$-a/Temp, Cu-a/EC, Cd-a/BOD, Cu-s/EC, Mn-s/BOD except Cd-s/Cd-a, Cd-s/BOD, Cu-s/EC and Mn-s/Temp, were negatively correlated. The rest of the pairs were not significantly correlated. Elemental and physico-chemical characteristic pairs in Table 10 shows that $\mathrm{Cu}-\mathrm{a} / \mathrm{Pb}-\mathrm{a}, \mathrm{Pb}-$ s/Pb-a, Cu-s/Pb-a, Pb-s/Cu-a, Fe-a/Mn-a, Cu-s/Pb-s, Zn-

Table 6: Bio-concentration Factor (BCF) values of heavy metals in algal biomass of Nakivubo stream, Tributaries and Watindo stream

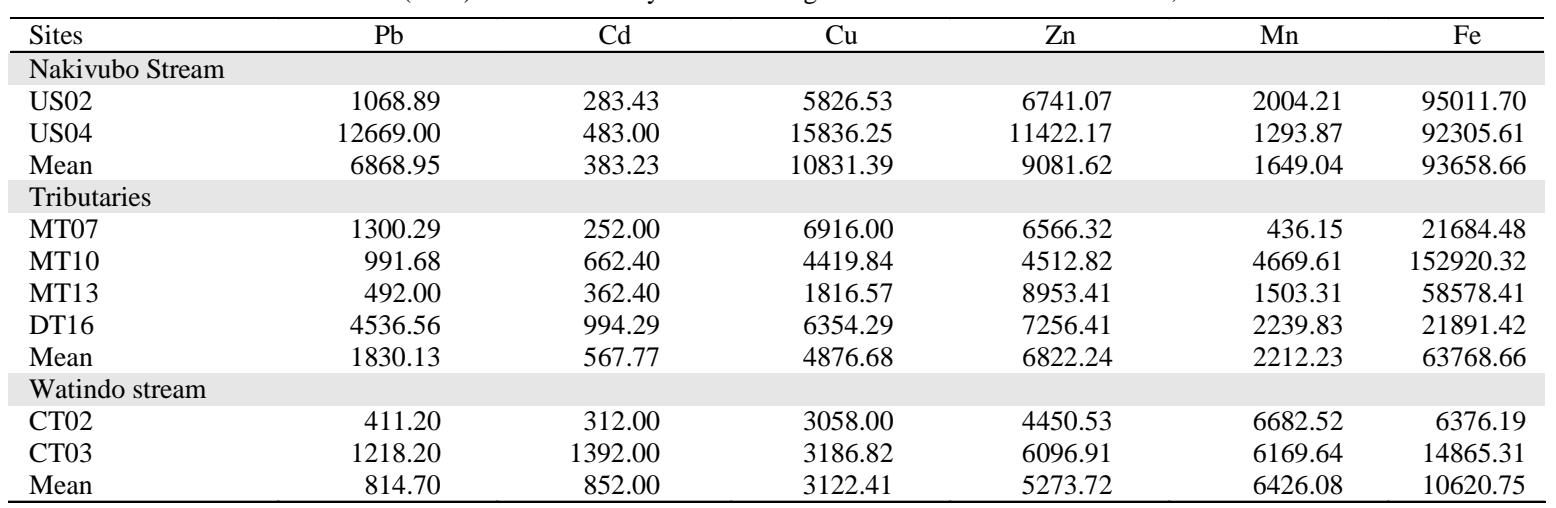



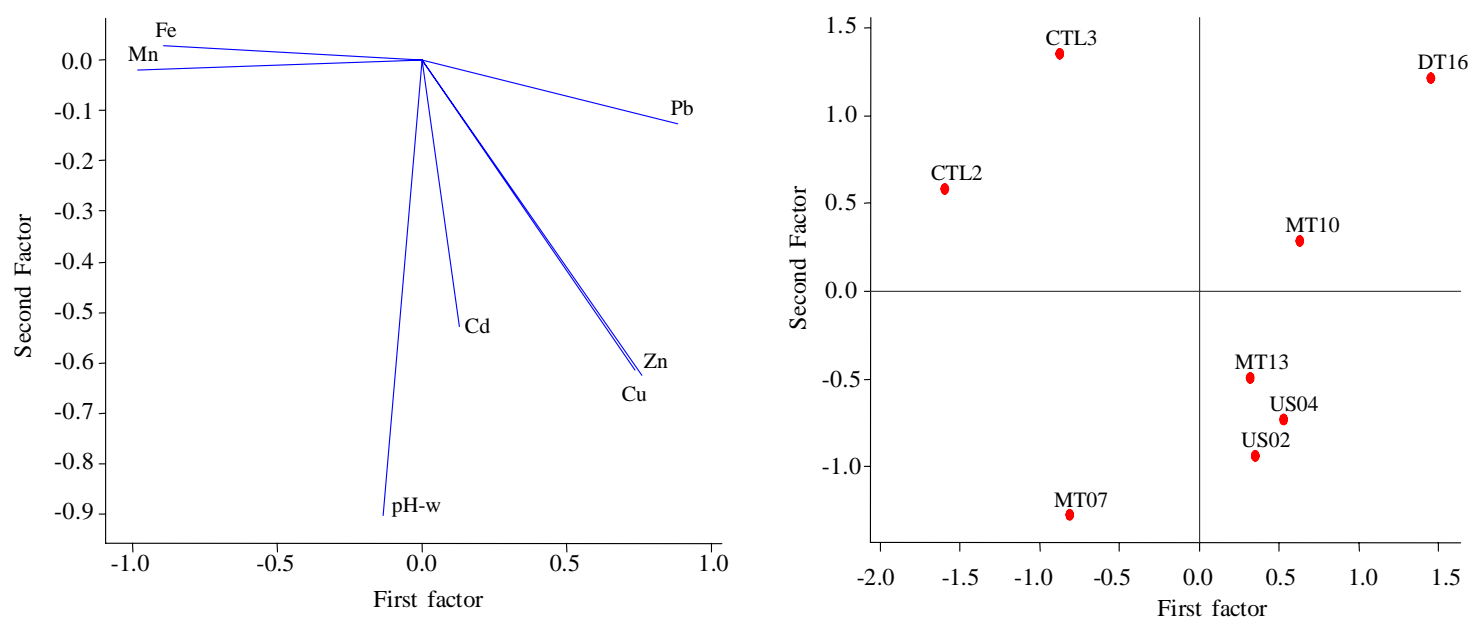

Fig. 2: Biplot of sites (a) along streams and elemental concentrations (b) of algal biomass

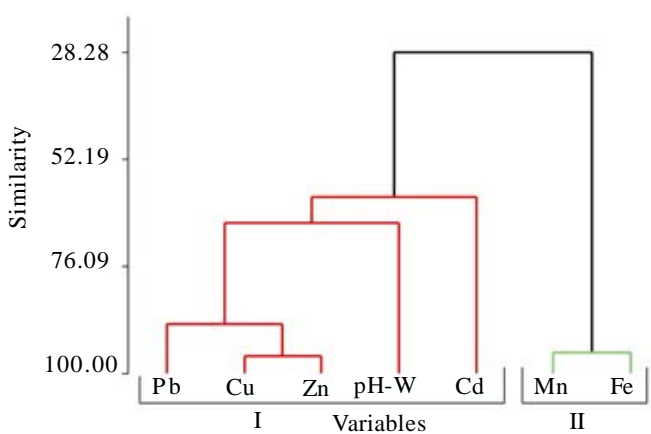

Fig. 3: Dendrogram of elemental concentrations in algal biomass and water $\mathrm{pH}$ of Nakivubo Channelized and Watindo streams

s/Pb-s Zn-s/Cu-s, Pb-w/Cu-s, Fe-s/Mn-s, Cu-w/Fe-s, Znw/Cd-w, Mn-w/Cd-w, Fe-w/Mn-a, Fe-w/Fe-a and Zn-a/ $\mathrm{pH}, \mathrm{Cd}-\mathrm{w} / \mathrm{pH}, \mathrm{Mn}-\mathrm{a} / \mathrm{BOD}$, as well as Fe-a/BOD are positively correlated with the same elements and each other. The rest of the pairs were not significantly correlated.

High correlation between $\mathrm{Cd}-\mathrm{s} / \mathrm{Cu}-\mathrm{a}$ and $\mathrm{Cu}-\mathrm{s} / \mathrm{Cu}-\mathrm{a}$ (Table 9 a) at site US02 suggests that the Car washing Bay and Kivuro slum establishment contribute to high $\mathrm{Cd}$ and $\mathrm{Cu}$ levels in stream sediments (Nyangababo and Ichikuni, 1986). Correlation coefficients between $\mathrm{Pb}-\mathrm{s} / \mathrm{Pb}-$ a, Fe-a/Cu-a, Zn-a/Cu-a, Fe-w/Cu-a, Mn-w/Zn-a, Fe-w/ Zn-a and Fe-a/Zn-a at site US04 indicate that vehicular emission contributes to high $\mathrm{Pb}, \mathrm{Cu}$ and $\mathrm{Zn}$ levels in the environment. Petrol combustion products contain lead and copper, whereas zinc may be a constituent of parts of vehicle engines. The high correlation of $\mathrm{Fe}-\mathrm{a} / \mathrm{Mn}-\mathrm{a}$ in algal biomass (Table 8 a and b, 9 a,b and d) possibly
Table 7: Varimax rotated Factor Loadings and Communalities of elements in algal biomass and water $\mathrm{pH}$ in Nakivubo Channelized and Watindo streams

\begin{tabular}{lrrc}
\hline Variables & Factor 1 & Factor 2 & Communality \\
\hline $\mathrm{Pb}$ & 0.885 & -0.126 & 0.800 \\
$\mathrm{Cd}$ & 0.131 & -0.530 & 0.298 \\
$\mathrm{Cu}$ & 0.759 & -0.624 & 0.965 \\
$\mathrm{Zn}$ & 0.736 & -0.615 & 0.920 \\
$\mathrm{Mn}$ & -0.985 & -0.020 & 0.971 \\
$\mathrm{Fe}$ & -0.897 & 0.027 & 0.806 \\
$\mathrm{pH}-\mathrm{w}$ & -0.134 & -0.902 & 0.832 \\
\hline Variance & 3.7112 & 1.8807 & 5.5919 \\
$\%$ Var. & 0.530 & 0.269 & 0.799 \\
\hline
\end{tabular}

suggests their essentiality for algal growth. The negative correlation coefficients between $\mathrm{Cu}-\mathrm{a} / \mathrm{Cd}$-a possibly suggests inhibition of uptake or adsorption of Cd by algae in preference for $\mathrm{Cu}$ as an essential element. The correlation of Cd-a/Pb-a, Cu-a/Cd-a, Zn-a/Cd-a, Pbw/Pba, Cu-w/Cd-a, Mn-a/Zn-a, Fe-a/Zn-a, Fe-a/Mn-a, Cu-w/ $\mathrm{Zn}-\mathrm{a}$ and $\mathrm{Cu}-\mathrm{w} / \mathrm{Fe}-\mathrm{a}$ along the Kayunga tributary may signify that each paired elements originate from identical source (Table 9 a). However, high correlation between these metal pairs possibly suggest that solid waste dumping along the sides of the tributary and vehicle traffic contribute to addition of $\mathrm{Cu}, \mathrm{Cd}, \mathrm{Pb}$ and $\mathrm{Zn}$ in the environment (stream water, sediments and algal biota). Elemental pairs along Kitante tributary (Table 9 b) indicate high correlation of Pb-s/Cd-a, Fe-a/Zn-a, Zn-s/Zn-a, Mn$\mathrm{s} / \mathrm{Zn}-\mathrm{a}$ and Fe-s/Zn-a in sediments. This suggests that hotels, residential establishment and vehicle traffic 

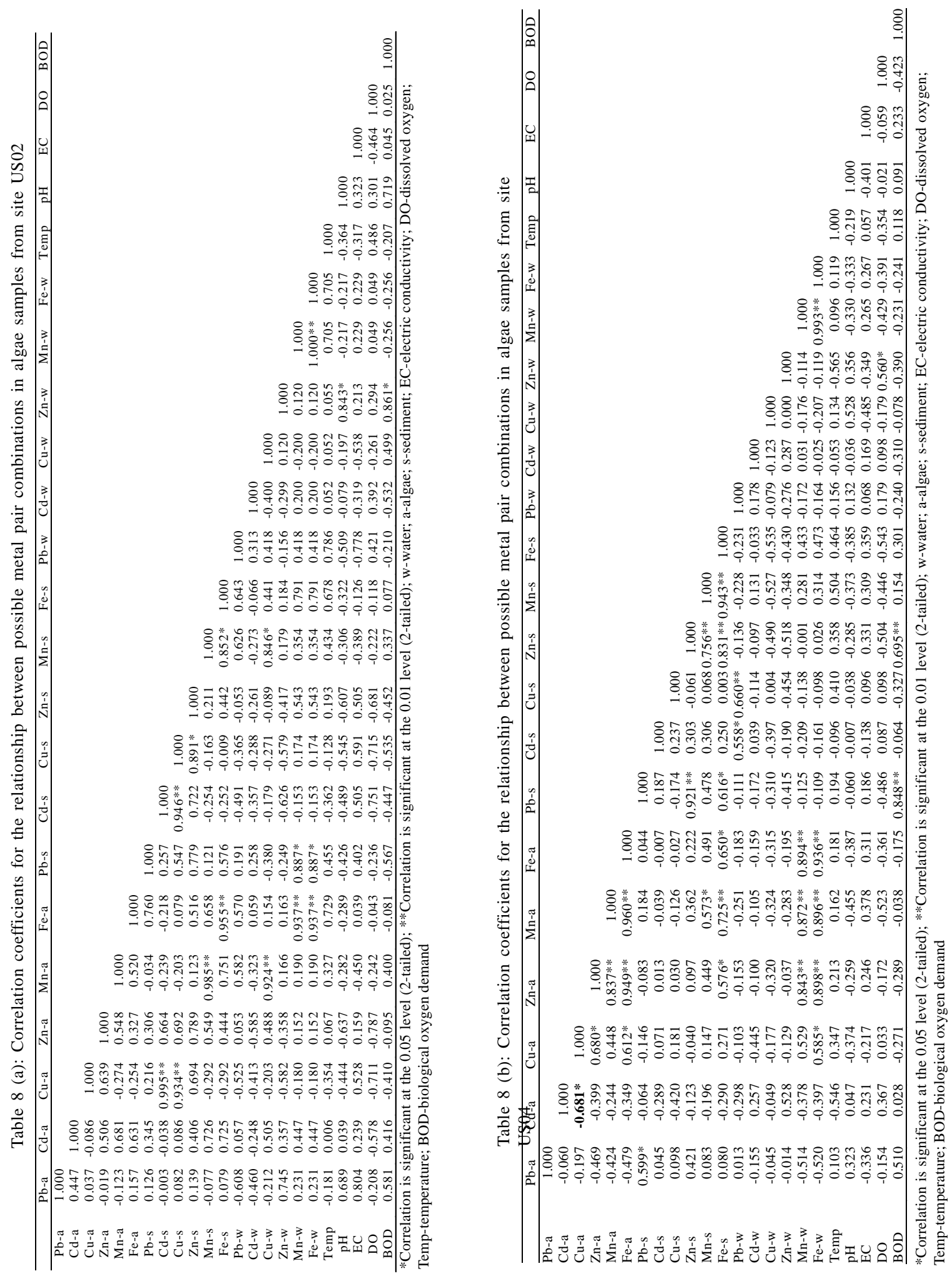
K. Sekabira et al.
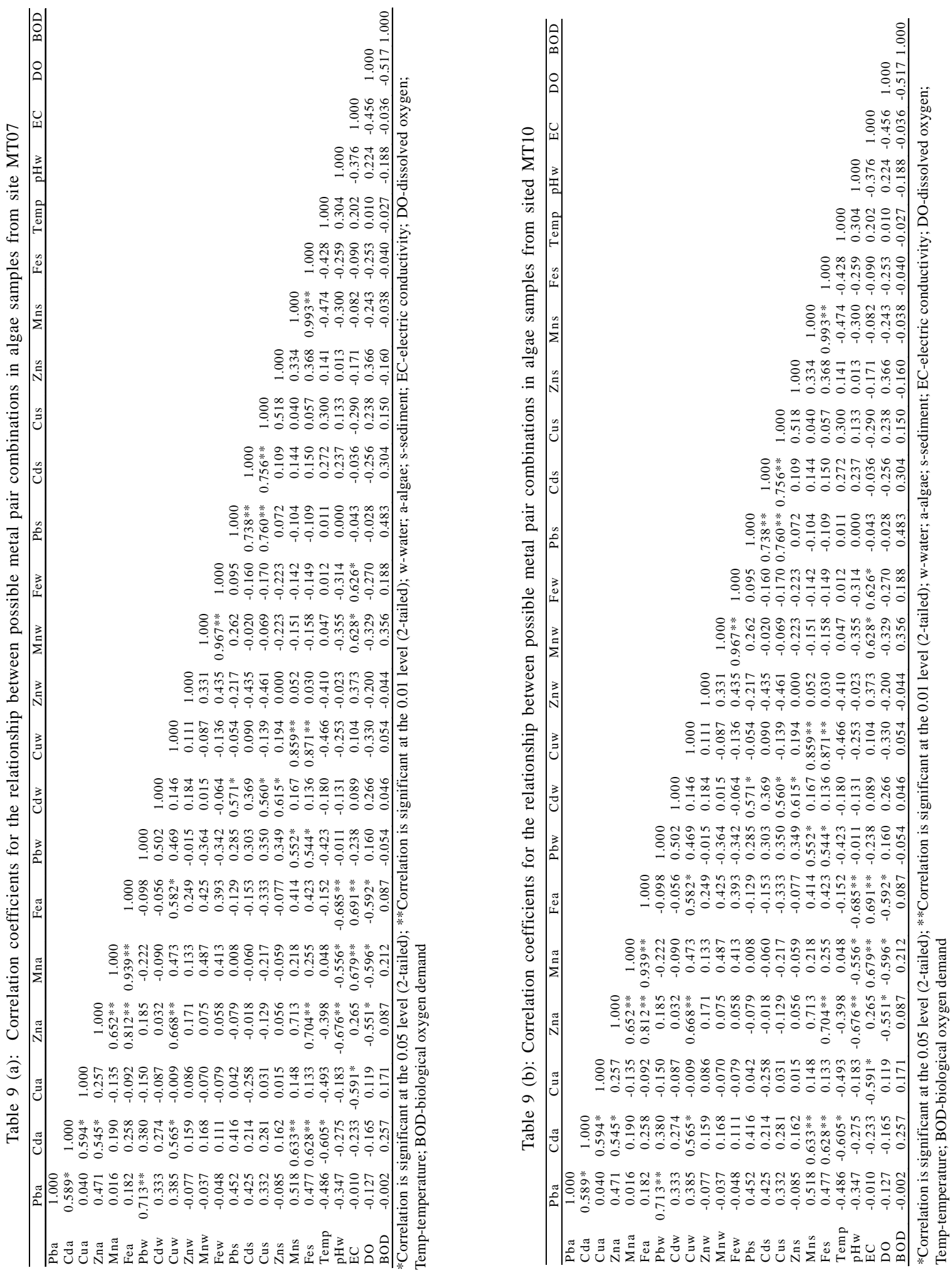
Int. J. Environ. Sci. Tech., 8 (1), 115-128, Winter 2011
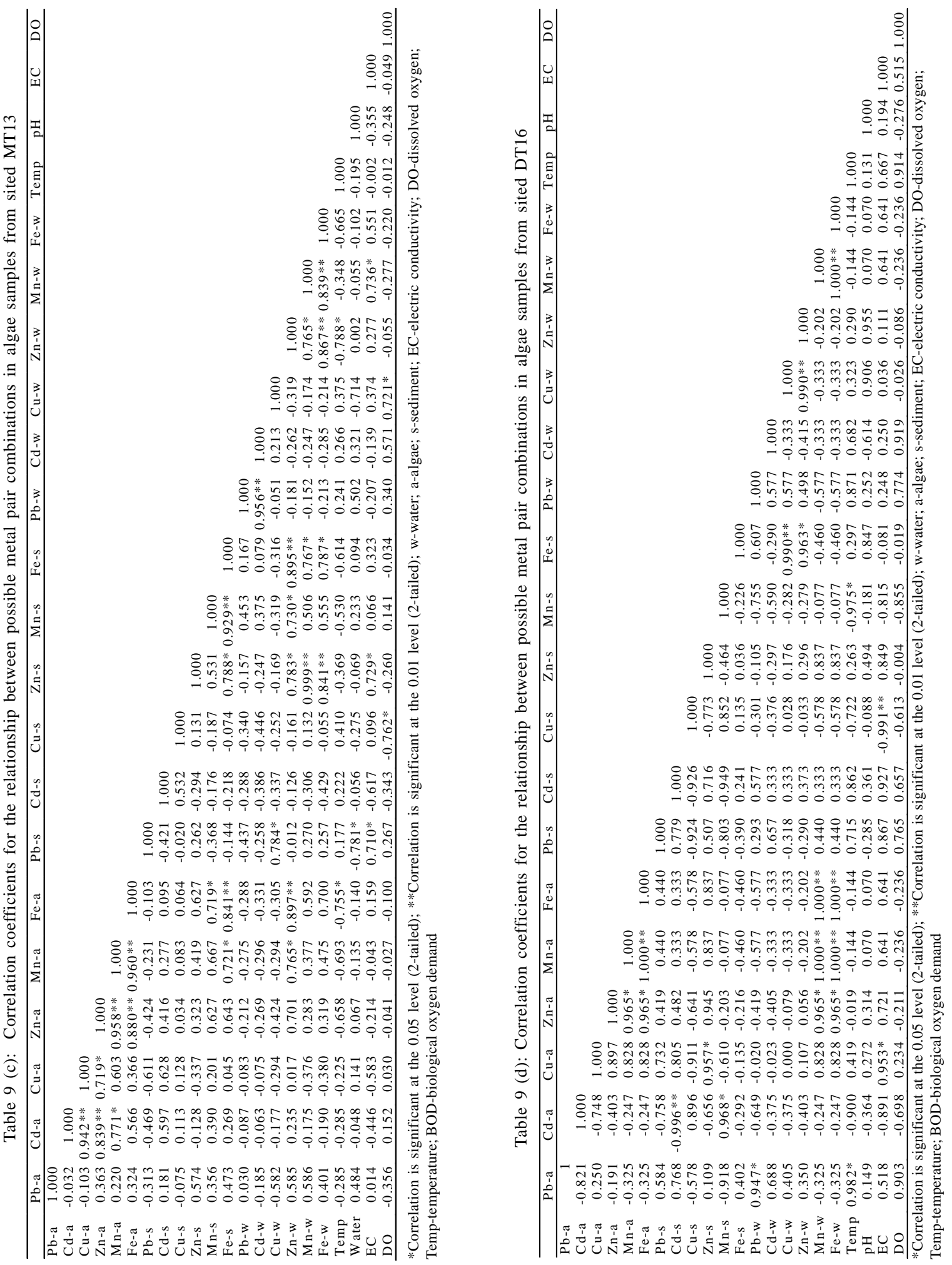
Heavy metal phytosorption by Algae in Nakivubo Channel

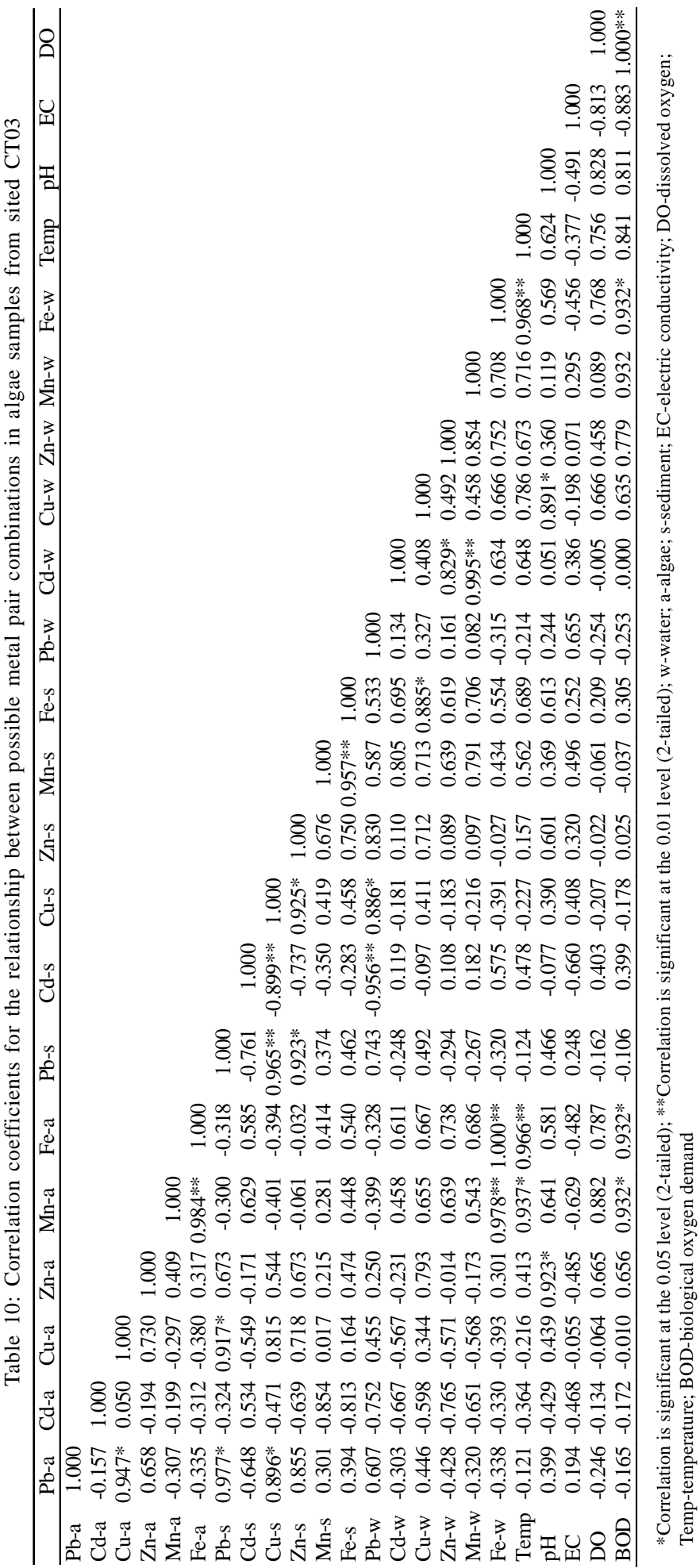


contribute $\mathrm{Pb}, \mathrm{Cd}$ and $\mathrm{Zn}$ to the environment. Also, high correlation of elemental pairs along the Lugogo tributary of Cu-a/Cd-a, Zn-s/Cd-a, Zn-a/Cu-a, Mn-a/Cda, Mn-a/Zn-a, Fe-a/Zn-a, Fe-a/Mn-a, Fe-s/Mn-a, Zn-w/ $\mathrm{Fe}-\mathrm{a}$, and $\mathrm{Zn}-\mathrm{w} / \mathrm{Mn}-\mathrm{a}$ indicates that petro stations, washing bays and vehicle traffic introduce high amounts of $\mathrm{Cu}, \mathrm{Cd}$ and $\mathrm{Zn}$ to the environment. Referring to Table 9 (c), high correlations of Cd-s/Cd-a, Mn-s/Cd-a, Pb-w/ Pba, Zn-s/Cu-a, Mn-a/Zn-a, Fe-a/Zn-a, Fe-a/Mn-a, Mnw/Zn-a, Fe-w/Zn-a, Mn-w/Mn-a, Fe-w/Fe-a and Mn-w/ Fe-a along the Kibira Road tributary were noted. This may indicate that industries contribute high levels of $\mathrm{Cd}, \mathrm{Zn}, \mathrm{Cu}$ and $\mathrm{Pb}$, since wastewater effluents from batteries (Uganda Batteries LTD), plastic (Uganda House of Plastics LTD) and Iron sheet (galvanised) (Uganda Baati LTD) factories contain these elements. Very high elemental pairs of $\mathrm{Cu}-\mathrm{a} / \mathrm{Pb}-\mathrm{a}, \mathrm{Pb}-\mathrm{s} / \mathrm{Pb}-\mathrm{a}, \mathrm{Cu}-\mathrm{s} / \mathrm{Pb}-\mathrm{a}, \mathrm{Pb}-$ s/Cu-a and $\mathrm{Fe}-\mathrm{a} / \mathrm{Mn}-\mathrm{a}$ (Table $9 \mathrm{~d}$ ) may be explained by the contribution from atmospheric deposition and/or geochemistry of the sediments (Chakravarty and Patgiri, 2009; Sekabira et al., 2010). Water pH was negatively correlated with heavy metal concentration in algal biomass, whereas it was positively correlated in Watindo stream, suggesting its influence on the adsorption and uptake of heavy metals.

\section{CONCLUSION}

This study indicates that the Nakivubo ecosystem is actively accumulating heavy metals in the environment and that algae have the potential to accumulate $\mathrm{Pb}, \mathrm{Cd}$, $\mathrm{Cu}$, and $\mathrm{Zn}$.

Algae can thus be used in bio-monitoring of heavy metal pollution in urban stream water since it can be used in quantification of pollutants. Concentrations of heavy metals in algal biomass reflect metal load in the stream water. Algae can therefore be used in the phytoextraction process of heavy metals in aquatic urban stream water and wastewater effluents.

Significant correlations of heavy metal concentrations in algal biomass with stream water and sediments and the ability to accumulate these heavy metals also strengthen algae as good bio-monitor of $\mathrm{Pb}, \mathrm{Cd}, \mathrm{Cu}$ and $\mathrm{Zn}$.

Bio-concentration factor (BCF) of heavy metals in algal biota was found in decreasing order of $\mathrm{Fe}>\mathrm{Cu}>\mathrm{Zn}>\mathrm{Pb}$ $>\mathrm{Mn}>\mathrm{Cd}$ in the Nakivubo Channelized stream.

\section{ACKNOWLEDGMENTS}

The authors are thankful to Kampala International University for the financial support in form of $\mathrm{PhD}$ research project and Department of Geology, Faculty of Science, Makerere University, for geochemical analyses.

\section{REFERENCES}

Baker, A. J. M.; Brooks, R. R., (1989). Terrestrial higher plants which hyperaccumulate metallic elements. A review of their distribution, ecology and phytochemistry. Biorecovery, 1 , 81-126 (46 pages).

Chakravarty, M.; Patgiri, A., D., (2009). Metal pollution assessment in sediments of the Dikrong river, N. E. India. J. Hum. Ecol., 27 (1), 63-67 (5 pages).

Chmielewská, E.; Medved', J., (2001). Bioaccumulation of heavy metals by green algae cladophora gramerata in a refinery sewage lagoon. Croat. Chem. 74 (1), 135-145 (11 pages).

Conti, M. E.; Cecchetti, G., (2003). Abiomonitoring study: Trace metals in algae and molluscs from yrrhenian coastal areas. Environ. Res., 93 (1), 99-112 (14 pages).

Eja, M. E.; Ogri O. R. A.; Arikpo G. E., (2003). Bioconcentration of heavy metals in surface sediments from the great Kwa rivers estuary, Calabar, South Eastern Nigeria. J. Nig. Environ. Soc. (2), 247-256 (10 pages).

Girgin, S.; Kazancý, N.; Dügel, M., (2010). Relationship between aquatic insects and heavy metals in an urban stream using multivariate techniques. Int. J. Environ. Sci. Tech., 7 (4), 653-664 (12 pages).

Goyal, P.; Sharma, P.; Srivastava, S.; Srivastava, M. M., (2008). Saraca indica leaf powder for decontamination of $\mathrm{Pb}$ : removal, recovery, adsorbent characterization and equilibrium modeling, Int. J. Environ. Sci. Tech., 5 (1), $27-$ 34 (8 pages).

Igwe, J. C.; Abia, A. A.; Ibeh, C. A., (2008). Adsorption kinetics and intraparticulate diffusivities of $\mathrm{Hg}$, $\mathrm{As}$ and $\mathrm{Pb}$ ions on unmodified and thiolated coconut fiber. Int. J. Environ. Sci. Tech., 5 (1), 83-92 (10 pages).

Kar, D.; Sur, P.; Mandal, S. K. ; Saha, T. ; Kole, R. K., (2008). Assessment of heavy metal pollution in surface water. Int. J. Environ. Sci. Tech., 5 (1), 119-124 (6 pages).

Kord, B.; Mataji, A.; Babaie, S., (2010). Pine (Pinus Eldarica Medw.) needles as indicator for heavy metals pollution, Int. J. Environ. Sci. Tech., 7 (1), 79-84 (6 pages).

Lam, P. K. S.; Gray, J. S., (2003). The use of biomarkers in environmental monitoring programmes. Mar. Pollut. Bull. 46: 182-186 (5 pages).

Levkov, Z.; Krstic, S., (2002). Use of algae for monitoring of heavy metals in the river Vardar, Macedonia. Mediterranean Mar. Sci., 3 (1), 99-112 (14 pages).

Muwanga, A.; Barifaijo, E., (2006). Impact of Industrial activities on heavy metal loading and their physicochemical effects on wetlands of lake Victoria basin (Uganda). Afri. J. Tech. Sci. Eng., 7 (1), 51-63 (13 pages).

Nabulo, G.; Oryem-Origa, H.; Nasinyama, G.; Cole, D., (2008). Assessment of $\mathrm{Zn}, \mathrm{Cu}, \mathrm{Pb}$, and $\mathrm{Ni}$ contamination in wetland soils and plants. Int. J. Environ . Sci. Tech. 5 (1), 413-422 (10 pages).

Nouri, J.; Khorasani, N.; Lorestani, B.; Karami, M.; Hassani, A. H.; Yousefi, N., (2009). Accumulation of heavy metals in soil and uptake by pnat species with phytoremediation potential. Environ. Earth Sci., 59 (2), 315-323 (9 pages).

Nwuche, C. O.; Ugoji, E. O., (2008). Effects of heavy metal pollution on the soil microbial activity, Int. J. Environ. Sci. Tech., 5 (3), 409-414 (6 pages). 
Nyangababo, J. T.; Henry, I. and Omutunge, E., (2005a). Heavy metal contamination in plants, sediments and air precipitation of Katonga, Simiyu and Nyando wetlands of Lake Victoria basin, East Africa. Bull. Environ. Contam. Toxicol., 75, 189-196 (10 pages).

Nyangababo, J. T.; Henry E.; Omutange E., (2005b). Lead, cadmium, copper, manganese and zinc in wetland waters of Victoria lake basin, East Africa. Bull. Environ. Contam. Toxicol. 74: 1003-1010 (8 pages).

Nyangababo, J. T.; Ichikuni, M., (1986). The use of Ceder Bark in the study of Heavy Metal Concentration in the Nagatsuta Area, Japan. Environ. Pollut. Ser. B 11: 211229.

Scott,C. D., (1992). Removal of dissolved metals by plant tissue. Biotech. Bioeng, 1062-1068 (7 pages).

Sekabira, K.; Oryem Origa, H.; Basamba, T. A.; Mutumba, G.; Kakudidi, E., (2010a). Assessment of heavy metal pollution in the urban stream sediments and its tributaries. Int. J. Environ. Sci. Tech., 7 (3), 435-446 (12 pages).
Sekabira, K.; Oryem Origa, H.; Basamba, T. A.; Mutumba, G.; Kakudidi, E., (2010b). Heavy metal assessment and water quality values in urban stream and rain water. Int. J. Environ. Sci. Tech., 7 (4), 759-770 (12 pages).

Shah, B. A.; Shah, V. A.; Singh, R. R., (2009). Sorption isotherms and kinetics of chromium uptake from wastewater using natural sorbent material, Int. J. Environ. Sci. Tech., 6 (1), 77-90 (14 pages).

Thangavel, P. and Subbhuraam, C. V., (2004). Phytoextraction: Role of Hyperaccumulator in Metal Contaminated Soils, Proc. Indian natn. Sci. Acad, B70 1: 109-130 (22 pages).

Wuana, R. A.; Okieimen, F. E.; Imborvungu, J. A., (2010). Removal of heavy metals from a contaminated soil using organic chelating acids, Int. J. Environ. Sci. Tech., 7 (3), 485-496 (12 pages).

Zayed, A.; Gowthaman, S.; Terry, N., (1998). Phytoaccumulation of trace elements by wetland plants: Duckweed. J. Environ. Qual., 27: 715-721 (7 pages).

AUTHOR (S) BIOSKETCHES

Sekabira, K., B.Sc, M.Sc, Ph.D. Candidate in Department of Environment, Faculty of Science and Engineering, Kampala International University, P. O. Box 20000, Kampala, Uganda. E-mail: ssekaba@gmail.com

Oryem Origa, H., Prof. B.Sc, M.Sc, PhD in Department of Botany, Faculty of Science, Makerere University, P. O. Box 7062, Kampala, Uganda. E-mail: horyem_origa@botany.mak.ac.ug

Basamba, T. A., B.Sc, M.Sc, PhD in Department of Soil Science, Faculty of Agriculture, Makerere University, P. O. Box 7062, Kampala, Uganda. E-mail: ateenyitwaha@hotmail.com

Mutumba, G., Ass. Prof. B.Sc, M.Sc, PhD in Department of Botany, Faculty of Science, Makerere University, P. O. Box 7062, Kampala, Uganda. E-mail: gmutumba@botany.mak.ac.ug

Kakudidi, E., B.Sc, M.Sc, PhD in Department of Botany, Faculty of Science, Makerere University, P. O. Box 7062, Kampala, Uganda. E-mail: ekakudidi@sci.mak.ac.ug

How to cite this article: (Harvard style)

Sekabira, K.; Oryem Origa, H.; Basamba, T. A.; Mutumba, G.; Kakudidi, E., (2010). Application of algae in biomonitoring and phytoextraction of heavy metals contamination in urban stream water. Int. J. Environ. Sci. Tech., 8 (1), 115-128. 